\title{
SENSORY PROFILE OF PORT WINES: CATEGORICAL PRINCIPAL COMPONENT ANALYSIS, AN APPROACH FOR SENSORY DATA TREATMENT
}

\author{
PERFIL SENSORIAL DE VINHOS DO PORTO: ANÁLISE EM COMPONENTES PRINCIPAIS \\ CATEGÓRICA, UMA ABORDAGEM PARA O TRATAMENTO DE DADOS SENSORIAIS
}

\author{
Alice Vilela $^{1} *$, Bebiana Monteiro ${ }^{1}$ and Elisete Correia ${ }^{2}$ \\ ${ }^{1}$ CQ-VR, Chemistry Research Centre, University of Trás-os-Montes and Alto Douro, Department of Biology and Environment, 5001-801 Vila \\ Real, Portugal. \\ ${ }^{2}$ CM-UTAD and, University of Trás-os-Montes and Alto Douro, Department of Mathematics, 5001801 Vila Real, Portugal.
}

*Corresponding author: Tel: +351 259350 592, fax +351 259350 480, e-mail: avimoura@utad.pt

(Received 27.11.2014. Accepted 08.01.2015)

SUMMARY

Port wine is a fortified wine. After the grape spirit addition the fermentation stops and the wine retains some of the natural sweetness of the grape. Port wine exhibits a variety of different styles, each with its own characteristic flavours: White Ports, Ruby Ports and Tawny Ports. Information about the wines sensory characteristics is critical for the successful development and marketing of each new wine brand. This type of information can be obtained using descriptive sensory tests with trained panels that can recognize different sensory descriptors in wines. Given that the collected variables are measured on an ordinal scale a Categorical Principal Component Analysis (CATPCA) can be performed. However, for many years, multivariate analysis has been used for wine characteristic evaluation and Principal Component Analysis (PCA) has long been applied to sensory data treatment.

The two main purposes of this study were to describe a specific sensory method, used by a trained sensory panel including chemical compounds reference development, to establish the most important descriptive and discriminative sensory attributes of different Port wine styles and brands and to compare the results of PCA with the results of CATPCA, in order to assess the feasibility of both techniques. At the end of the work we have demonstrated that the CATPCA data analysis seems to be more robust and explained 15\% more of the total amount of initial variance than PCA. Moreover, the CATPCA model did not highlight differences among wines from winery brands while, in PCA, Port Wines are grouped according to wine style and there are some discrimination between brands.

\section{RESUMO}

O vinho do Porto é um vinho fortificado. Após a adição de aguardente ao mosto/vinho a fermentar, a fermentação termina e o vinho resultante apresentará um pouco da doçura natural da uva. O Vinho do Porto ostenta uma variedade de estilos, cada um com os seus sabores e aromas característicos: Portos Brancos, Portos Ruby e Tawnies. Uma boa caracterização sensorial é fundamental para o desenvolvimento e comercialização de cada nova marca de Vinho do Porto. Esta caracterização pode ser obtida por meio de testes sensoriais descritivos com painéis de provadores treinados que podem reconhecer diferentes descritores sensoriais. Dado que as variáveis recolhidas são medidos numa escala ordinal uma Análise em Componentes Principais Categórica (ACPCAT) pode ser realizada. No entanto, há muitos anos que a análise estatística multivariada é utilizada para tratamentos de dados sensoriais, nomeadamente a Análise em Componentes Principais (ACP).

Os dois principais objetivos deste estudo foram descrever um método sensorial específico, usada por um painel de provadores treinados, incluindo o desenvolvimento de compostos químicos de referência, para os atributos sensoriais descritivos e discriminativos mais importantes nos diferentes estilos e marcas de vinho do Porto e comparar os resultados da ACP com os resultados da ACPCAT, a fim de avaliar a viabilidade de ambas as técnicas. No final do trabalho demonstramos que a análise dos dados ACPCAT parece ser mais robusta e explica mais de 15\% da variação inicial do que a análise ACP. Além disso, o modelo ACPCAT não destaca as diferenças entre os vinhos do mesmo estilo mas de marcas diferentes, enquanto, na análise ACP, os Vinhos do Porto são agrupados de acordo com o estilo de vinho e há alguma discriminação entre as marcas.

Key words: Port wines descriptors, sensory profile, CATPCA analysis, PCA analysis.

Palavras-chave: Descritores de vinhos do Porto, perfil sensorial, análise ACPCAT, análise ACP. 


\section{INTRODUCTION}

Port wine is a fortified wine made by adding a proportion of grape spirit, or brandy, to the wine before the must/wine has finished fermenting. After the grape spirit addition the fermentation stops and the wine retains some of the natural sweetness of the grape, making it rich, round and smooth on the palate. One of the interesting aspects of Port wine is its variety of different styles, each with its own characteristic flavours. Ruby, Reserve Ports and Late Bottled Vintage Ports (LBV) aged usually in vat for two, three years or even six years (LBV) share a deep red youthful colour and intense fruity flavours, reminiscent of cherry, blackberry and blackcurrant. Tawny Ports (10, 20, 30 and 40 year old tawny), which age for longer periods in oak casks, present delicious nuttiness and aromas of butterscotch and fine oak wood; White Ports, made from classic white grapes, usually aged for two or three years in large vats and are available in sweeter or drier styles.

In the Portuguese market, within each Port wine style, there are several Port wine brands. Brand management in today's business world is extremely related to the organizations purpose and improvement of their strategies (Miralles et al., 2008). Information about the wines sensory characteristics is critical for the successful development and marketing of each new wine brand. This type of information can be obtained using descriptive sensory tests with trained panels (Meilgaard et al., 1999; Stone and Sidel, 2004).

Aiming at detecting different sensory descriptors in wines, and given that the collected variables are measured on an ordinal scale a Categorical Principal Component Analysis (CATPCA) can be performed. In analyzing ordinal variables it should be taken into account that the categories of the variable have a fixed a priori order, but this does not imply that the differences between numeric labels of the categories are maintained. As known, in sensory sciences many variables are nominal or ordinal and relationships between variables are frequently nonlinear. Hence, linear or standard PCA could be not appropriate and should be used only after linearity in ordinal variables has been verified. In fact, multivariate analysis has been used for wine characteristic evaluation and Principal Component Analysis (PCA) has long been applied to sensory data treatment (Noble and Shannon, 1987; Zamora and Guirao, 2002; Vilanova et al., 2008, 2009; Rodriguez-Nogales et al., 2009; Esti et al., 2010; Dreyer et al., 2013; Liang et al., 2013). During the last years, nonlinear PCA has been introduced and developed to avoid the limitations of standard PCA (Gifi, 1990; Linting et al., 2007). The
CATPCA procedure (Meulman et al., 2004) belongs to such class of methods, and it is based on quantification of categorical variables by applying optimal scaling technique. The CATPCA finds category quantifications that are optimal in the sense that the overall variance accounted for in the transformed variables, given the number of components, is maximized. In the optimal scaling process, information in the original categorical data is retained in the optimal quantifications, depending upon the optimal scaling level that can be chosen for each variable separately (Meulman et al., 2004).

The two main purposes of this study were to describe a specific sensory method, used by a trained sensory panel (Monteiro et al., 2014), including chemical compounds reference development, to establish the most important descriptive and discriminative sensory attributes of different Port wine styles and brands and to compare the results of Principal Component Analysis (PCA) with the results of Categorical of Principal Component Analysis (CATPCA), in order to assess the feasibility of both techniques.

\section{MATERIAL AND METHODS}

\section{Wines}

In this study were evaluated 28 samples of Port wines from 3 different styles: ten White Ports; nine Ruby Ports and nine Tawny Ports, all from different Demarcated Douro Region (DDR) wineries, with cellars in Oporto (Table I). The brands are coded in our work, to avoid revealing commercial names. These wines were commercial wines presented in bottles of $0.75 \mathrm{~L}$, and produced according to the process of each winery/wine cellar. The bottles were stored in a cellar, lying down and under the same conditions - relative humidity around $85 \%$ and at a temperature around $12^{\circ} \mathrm{C}$. Prior to each tasting session the bottles were maintained at $12^{\circ} \mathrm{C}$ until tasting.

Table I

Wine samples evaluated and respective code numbers

Amostras de vinho avaliadas e respetivos códigos

\begin{tabular}{cc}
\hline Wine Style & $\begin{array}{c}\text { Brand (B), style and Bottle } \\
\text { number }\end{array}$ \\
\hline White Ports (W) & BW1 to BW10 \\
Ruby Ports (R) & BR11 to BR19 \\
Tawny Ports (T) & BT20 to BT28 \\
\hline
\end{tabular}

Selection of descriptors for Port wines and development of references

Two wines of each Port style were tasted and discussed by twelve trained panelists over three 
tasting sessions in an attempt to generate terms. A free choice of attributes to describe Port was used. Each session lasted around 1 hour. In all the sessions, the Wine Aroma Wheel (Noble and Shannon, 1987) was provided to facilitate term generation. Appearance (colour and clarity), aroma, taste, flavour and mouthfeel references were provided to facilitate the discussion. From an original long list of attributes, a reduced list was compiled by analyzing the frequency of citations. For the development of quantitative references, in order to make reference evaluation as close as possible to wine-tasting conditions, identical glasses as used for wine evaluation (ISO, 1977) were used for the aroma reference presentation.

In an attempt to make the panelists more familiar with the wines, during the reference defining sessions, three wines, one of each style, were evaluated and discussed. After all the references were developed, 3 training sessions were carried out according to the methodology that would be used to evaluate the wines.

\section{Wine Tasting}

In this study we analyzed 28 Port wines available in the Portuguese market. All the wines were evaluated in triplicate in nine tasting sessions, one session per week, from 10.00 to 12:00 a.m. The wines were randomly distributed throughout the sessions of each series in a way that the three replications were consecutive: all the samples were assessed once, then a second time and then a third time.

Sessions were carried out under controlled temperature conditions $\left(20 \pm 2{ }^{\circ} \mathrm{C}\right)$ and relative humidity $(60 \pm 20 \%)$. Aroma references (Table II) were served in standardized wine-tasting glasses (ISO, 1977). Wine bottles were opened immediately before tasting, and $35 \mathrm{~mL}$ samples of each wine were served in standardized glasses. Reference and wine glasses were covered with Petri dishes and were immediately brought to the tasting booths in the sensory evaluation laboratory.

The references and wines were evaluated in isolated booths according to the methodology describe by Monteiro et al. (2014). Attribute intensities were scored on a 5-point scale (ranging from 1-lowest intensity to 5 -highest intensity) by comparison with the intensity of the references. References and samples were expectorated. The panelists were instructed to rinse their mouth with water between references and between wines, as well as to use unsalted crackers to decrease astringency carryover. The panelists were told to have a rest and to leave the tasting room if necessary.

\section{Data Analysis}

All statistical analysis was performed using SPSS (IBM SPSS Statistics 20). In order to establish the most important descriptive and discriminative sensory attributes of different Port wine styles and brands, Principle Component Analysis (PCA) and Categorical Principle Component Analysis (CATPCA) were applied on the data set of 23 attributes.

\section{RESULTS AND DISCUSSION}

With the aim of establishing and interpreting the sensory descriptors of 28 Port Wines, a PCA was applied on the total data set of 23 attributes. To use a PCA is necessary to check some assumptions namely, the Bartlett test of sphericity (Hair et al., 2009), a statistical test for the presence of correlation among the variables, and the measure of sampling adequacy of Kaiser-Meyer-Olkin (KMO) (Hair et al., 2009), which must exceed 0.5 . As shown in Table III, a statistically significant Bartlett's test of sphericity, $\operatorname{sig}=0.00$, indicates that sufficient correlation exists among the variables yet, a lower value of $\mathrm{KMO}$, 0.209 , indicates a not good sampling adequacy.

The two-dimensional model, Table IV, yields an eigenvalue of 9.304 for the first component, indicating that $40.451 \%$ of total variability is explained by this component and an eigenvalue of 4.451 for the second component, indicating that its proportion of variance is $19.874 \%$. Thus, the two components explained $60.325 \%$ of the total amount of initial variance.

The principal components are illustrated in Figure 1. The model did not highlight differences among wines from winery brands, however wine samples are grouped on the plane according to wine style. As we said before a PCA was applied on the data set of 23 attributes, but, only 19 of them contributed to the two-dimensional model in a meaningful way (factor loadings $>0.5$, Table V), then the first component (PC1) was best described by attributes: Golden, Ruby, Honey, Woody, Sweet taste, Persistence, Alcoholic sensation, Balance, Red fruits, Fruity flavour, Red Fruit flavour, Fruity, Astringency, Floral and Moscatel. The second component (PC2) was characterized by attributes such as: Golden, Ruby, Clean, Citrus, Red fruits, Sweet taste, Dried fruits, Floral and Dried fruits flavour.

The first principal component distinguishes Ruby brands, located on the positive axis from White brands on the negative axis. In the Ruby brands, the attributes Ruby, Persistence, Red fruits, Astringency and Floral were dominant, whereas in the White 
brands, attributes like Honey, Sweet taste, Alcoholic sensation, Balance, and Moscatel are the ones that better characterize these wines. However the wine BW7 (White Port Wine sample number seven) is better characterized by the attributes Golden and Woody. Tawny Port Wines are characterized by the nasal and ortho-nasal attributes and Dried fruits flavour and Dried fruits.

Table II

Descriptors or attributes for Port wines White, Ruby and Tawny with more citations and respective references. The aroma was perceived as an ortho-nasal perception and flavour as a retro nasal perception

Descritores ou atributos de vinhos do Porto Branco, Ruby e Tawny com mais citações e respetivas referências. O aroma era percebido como uma perceção ortonasal e o flavour como uma perceção retronasal

\begin{tabular}{|c|c|c|c|}
\hline Attribute $^{(1)}$ & Sensory definition & Reference & $\begin{array}{c}\text { Position on the } \\
\text { scale }^{(2)}\end{array}$ \\
\hline Golden & Intensity of wine's yellow/golden color. & Brand of Tawny Port wine (T22). & 4 \\
\hline Ruby & Intensity of wine's ruby color. & Brand of Ruby Port wine (R21). & 4 \\
\hline Clean & Clarity of wine's color. & Brand of Ruby Port wine (R21). & 4 \\
\hline Fruity (aroma) & $\begin{array}{l}\text { Aroma associated to tree fruits like peach, } \\
\text { apple, apricot, plum. }\end{array}$ & $\begin{array}{l}\text { Natural products placed in sensory tasting } \\
\text { glasses. }\end{array}$ & 5 \\
\hline Honey (aroma) & Aroma associated to honey. & $\begin{array}{l}2 \text { teaspoons of multi floral honey in } 100 \mathrm{ml} \text { of } \\
\text { a hydro alcoholic solution, } 19 \%(\mathrm{v} / \mathrm{v}) \mathrm{in} \\
\text { ethanol. }\end{array}$ & 4 \\
\hline Woody (aroma) & Aroma associated to barrels, wood. & $\begin{array}{l}\text { Maceration of } 1.0 \mathrm{gl}^{-1} \text { of French oak chips, } \\
\text { medium toast, in ethanol }(19 \%, \mathrm{v} / \mathrm{v}) \text {. }\end{array}$ & 5 \\
\hline Citrus (aroma) & $\begin{array}{l}\text { Aroma associated to citrus as lemon, orange, } \\
\text { mandarin. }\end{array}$ & $\begin{array}{l}\text { Natural products placed in sensory tasting } \\
\text { glasses. }\end{array}$ & 5 \\
\hline Red fruits (aroma) & $\begin{array}{l}\text { Aroma associated to berries, as raspberry } \\
\text { and strawberry. }\end{array}$ & $\begin{array}{l}\text { Natural products placed in sensory tasting } \\
\text { glasses. }\end{array}$ & 5 \\
\hline Dried fruits (aroma) & $\begin{array}{l}\text { Aroma associated to dried fruits such us } \\
\text { almonds, nutmegs and raisins. }\end{array}$ & $\begin{array}{l}\text { Maceration of } 10 \mathrm{~g} \text { of almonds, nutmegs and } \\
\text { raisins in } 100 \mathrm{ml} \text { of a hydro alcoholic solution, } \\
19 \%(\mathrm{v} / \mathrm{v}) \text { in ethanol. }\end{array}$ & 5 \\
\hline Floral (aroma) & $\begin{array}{l}\text { Aroma associated to flowers, namely } \\
\text { lavender. }\end{array}$ & $\begin{array}{l}\text { Linalool, } 100 \mu \mathrm{g} / 1 \text { in } 1 \mathrm{~L} \text { of a hydro alcoholic } \\
\text { solution, } 19 \%(\mathrm{v} / \mathrm{v}) \text { in ethanol }\end{array}$ & \\
\hline Red fruit (flavour) & $\begin{array}{l}\text { Flavour associated to berries, as raspberry } \\
\text { and strawberry. }\end{array}$ & $\begin{array}{l}\text { Natural products placed in sensory tasting } \\
\text { glasses. }\end{array}$ & 5 \\
\hline Fruity (flavour) & $\begin{array}{l}\text { Flavour associated to tree fruits like peach, } \\
\text { apple, apricot, plum. }\end{array}$ & $\begin{array}{l}\text { Natural products placed in sensory tasting } \\
\text { glasses. }\end{array}$ & 5 \\
\hline Moscatel (flavour) & $\begin{array}{l}\text { Flavour associated with the wine from the } \\
\text { Portuguese grape variety "Moscatel". }\end{array}$ & Brand of Portuguese Moscatel wine (M22). & 5 \\
\hline $\begin{array}{l}\text { Dried fruits } \\
\text { (flavour) }\end{array}$ & $\begin{array}{l}\text { Flavour associated to dried fruits such us } \\
\text { almonds, nutmegs and raisins. }\end{array}$ & $\begin{array}{l}\text { Maceration of } 10 \mathrm{~g} \text { of almonds, nutmegs and } \\
\text { raisins in } 100 \mathrm{ml} \text { of a hydro alcoholic solution, } \\
19 \%(\mathrm{v} / \mathrm{v}) \text { in ethanol }\end{array}$ & 5 \\
\hline Sweet taste & $\begin{array}{l}\text { Sensation produced by an aqueous solution } \\
\text { of sucrose. }\end{array}$ & $\begin{array}{l}\text { Wine-like solution with sucrose with } 2.8^{\circ} \\
\text { Baumé and ethanol }(19 \%, \mathrm{v} / \mathrm{v})\end{array}$ & 4 \\
\hline Acid taste & $\begin{array}{l}\text { Sensation produced by aqueous solutions of } \\
\text { acid substances, as citric acid or tartaric } \\
\text { acid. }\end{array}$ & $\begin{array}{l}\text { Solution of } 5.0 \mathrm{gl}^{-1} \text { solution of tartaric acid and } \\
0.5 \mathrm{gl}^{-1} \text { of citric acid. }\end{array}$ & 5 \\
\hline Alcoholic sensation & Burning sensation in the mouth & $35 \mathrm{ml}$ solution of "aguardente" $(19 \% \mathrm{v} / \mathrm{v})$ & 4 \\
\hline $\begin{array}{l}\text { Soft sensation } \\
\text { (mouthfeel) }\end{array}$ & Smooth feel in the mouth & $\begin{array}{l}\text { Brand of Tawny Port wine (T22) added with } \\
\text { glycerol }\left(30 \mathrm{gl}^{-1}\right) \text {. }\end{array}$ & 4 \\
\hline $\begin{array}{l}\text { Spicy sensation } \\
\text { (mouthfeel) }\end{array}$ & Sensation associated with pepper & One tea spoon of pepper in $1 \mathrm{~L}$ of water. & 3 \\
\hline $\begin{array}{l}\text { Astringency } \\
\text { (mouthfeel) }\end{array}$ & $\begin{array}{l}\text { Dry, puckering mouthfeel caused by wine } \\
\text { tannins. }\end{array}$ & $\begin{array}{l}100 \mathrm{mg} \text { of oenological tannins in } 1 \mathrm{~L} \text { of a hydro } \\
\text { alcoholic solution, } 19 \%(\mathrm{v} / \mathrm{v}) \text { in ethanol. }\end{array}$ & 5 \\
\hline Body (mouthfeel) & $\begin{array}{l}\text { Consistency or density in the mouth, volume } \\
\text { in the mouth }\end{array}$ & Brand of Ruby Port wine (R24) & 4 \\
\hline Balance & $\begin{array}{l}\text { Situation where acidity, astringency and, if } \\
\text { present, bitterness, are compensated by } \\
\text { sweetness. }\end{array}$ & Brand of Ruby Port wine (R21). & 3 \\
\hline $\begin{array}{l}\text { Persistence } \\
\text { (after-taste) }\end{array}$ & $\begin{array}{l}\text { Duration of overall flavour and mouthfeel } \\
\text { that reminds, after spitting the wine. }\end{array}$ & Brand of Ruby Port wine (R24) - 8 seconds. & 4 \\
\hline \multicolumn{4}{|c|}{$\begin{array}{l}\text { (1) Only descriptors/attributes that had a frequency of citation higher than } 2.5 \% \text { were used. } \\
\text { (2) Nominal scale for aroma and flavour attributes intensity scoring: }\end{array}$} \\
\hline \multicolumn{2}{|c|}{ The attribute is not perceived at all } & 1 & \\
\hline \multicolumn{2}{|c|}{ Doubts about the presence of the attribute } & 2 & \\
\hline \multicolumn{2}{|c|}{ The attribute is clearly perceived, although it is slight } & 3 & \\
\hline \multicolumn{3}{|c|}{ The attribute is clearly perceived, but the intensity is lower than the reference } & \\
\hline \multicolumn{3}{|c|}{ The attribute is clearly perceived and the intensity is close or similar to the reference } & \\
\hline
\end{tabular}




\section{Table III}

KMO and Bartlett's Test (PCA analysis)

KMO e Teste de Bartlett (análise ACP)

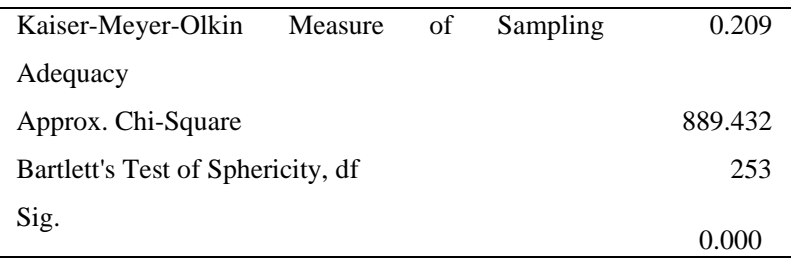

When we used a Categorical principal components analysis the two-dimensional model has an internal consistency coefficient (Cronbach's Alpha) of 0.954 and yields an eigenvalue of 11.383 for the first component, indicating that $49.492 \%$ of the variance is accounted by this component (Table VI). For the second component the internal consistency coefficient is 0.862 with an eigenvalue of 5.695 , indicating that its proportion of variance is $24.761 \%$. Thus, the two components explained $74.253 \%$ of the total amount of initial variance (Table VI), a higher value than the one achieved with PCA analysis.

Table IV

Eigenvalues obtained by the two-dimensional PCA model

Eigenvalues obtidos pelo modelo bidimensional ACP

\begin{tabular}{cccccc}
\hline \multicolumn{5}{c}{ Total Variance Explained } \\
\hline & Initial Eigenvalues & \multicolumn{4}{c}{ Extraction Sums of Squared Loadings } \\
\hline Total & \% of Variance & Cumulative \% & Total & \% of Variance & Cumulative \% \\
\hline 9.304 & 40.451 & 40.451 & 9.304 & 39.850 & 39.850 \\
4.571 & 19.874 & 60.325 & 4.571 & 19.874 & 60.325 \\
\hline
\end{tabular}

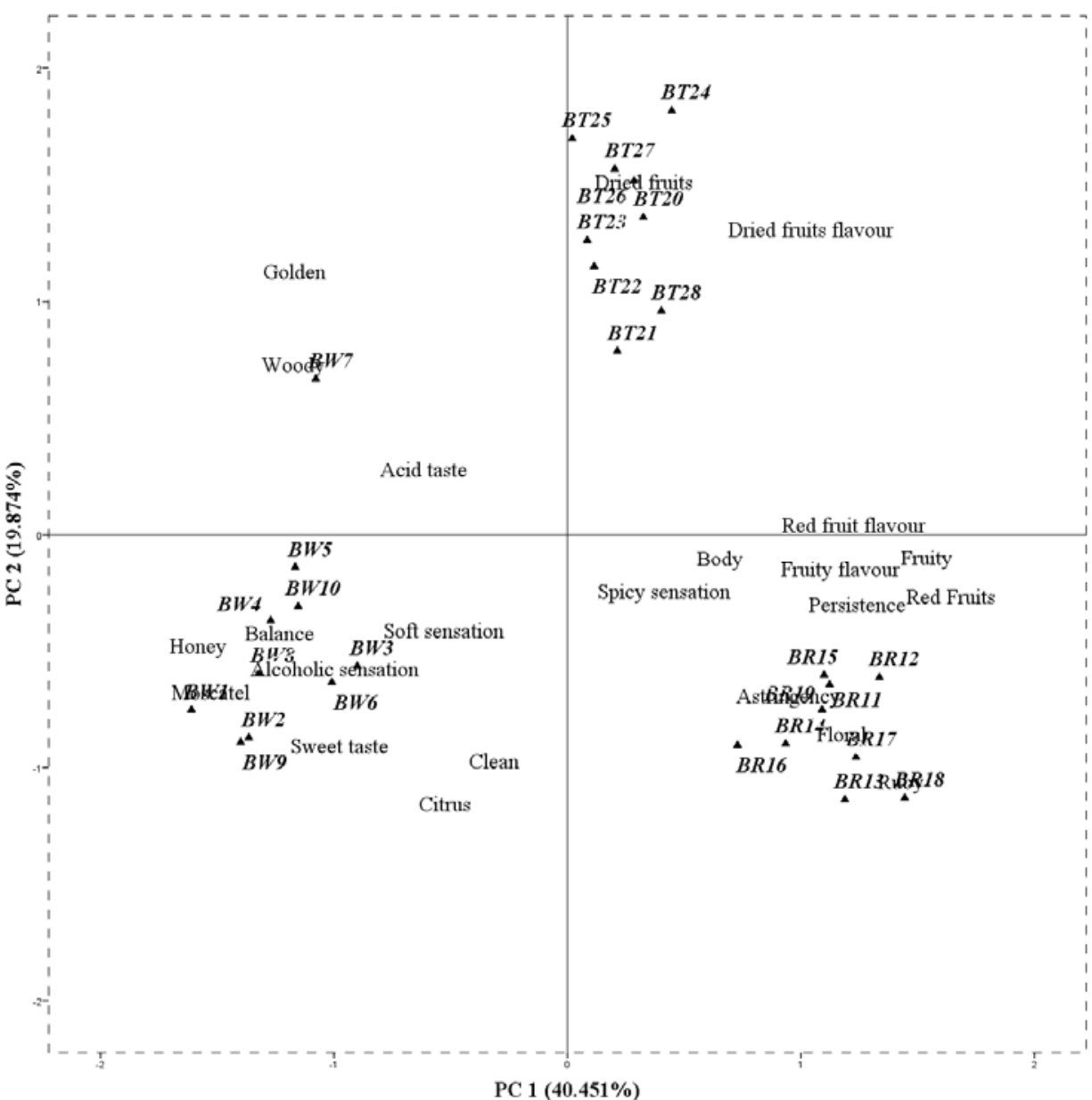

Figure 1. PCA loadings and scores of the sensory attributes and wines for components 1 and 2.

Projeção dos valores dos atributos sensoriais dos vinhos avaliados, nas componentes 1 e 2, após a ACP.

For the 28 Port Wines we obtained a biplot (Figure 2) with each attribute and each wine plotted along dimension 1 and dimension 2. The attributes (factor loadings $>0.5$, Table VII) that best describe the first 
component are: Golden, Ruby, Honey, Woody, Sweet taste, Persistence, Alcoholic sensation, Acid taste, Balance, Red fruits, Fruity flavour, Red Fruit flavour, Fruity, Astringency, Floral, Moscatel and Dried fruits flavour. The second component (PC2) was characterized by attributes such as: Golden, Ruby, Clean, Woody, Citrus, Red fruits, Dried fruits, Floral and Dried fruits flavour.

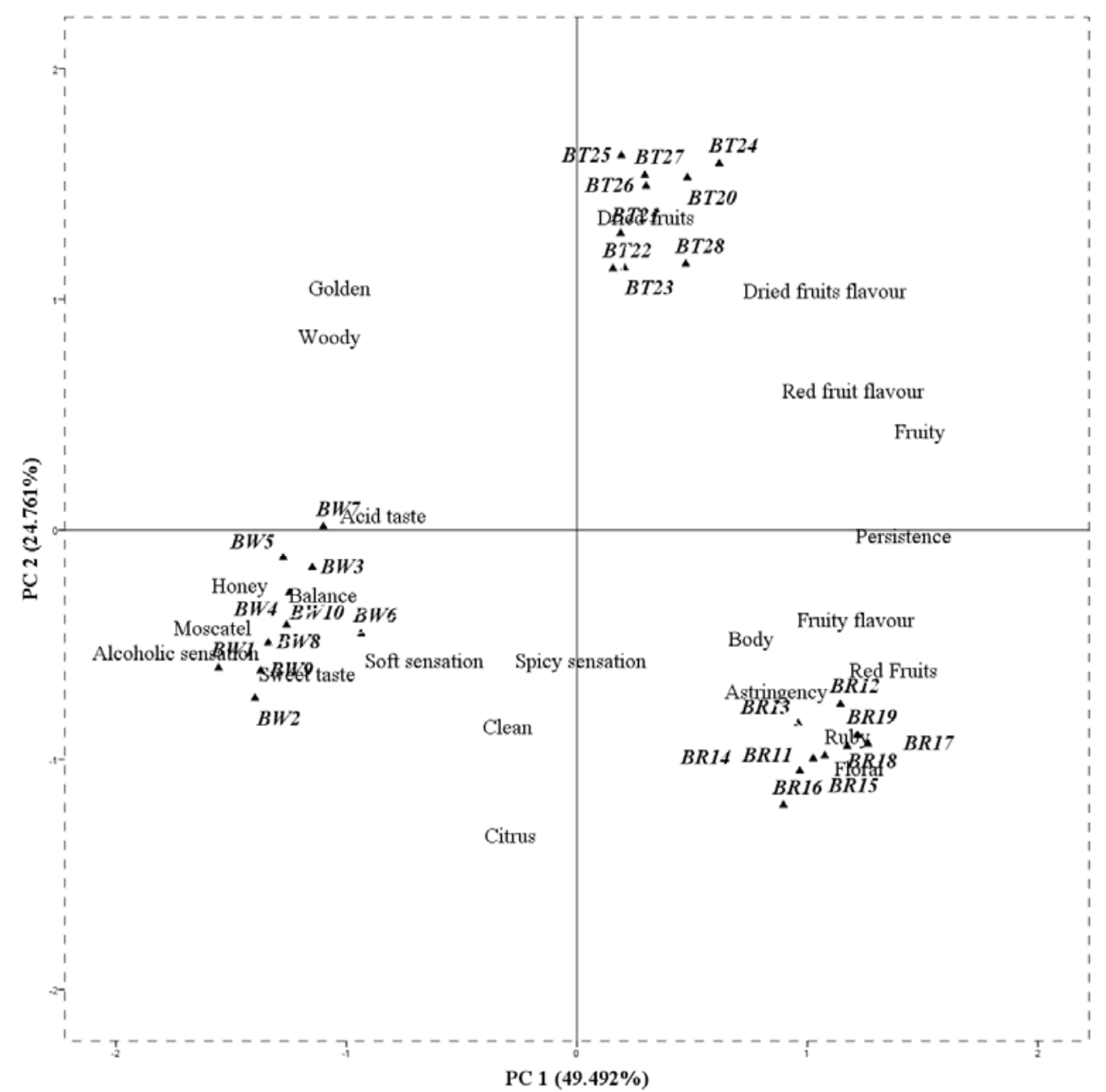

Figure 2. CATPCA principal components loadings and scores of the sensory attributes and wines for components 1 and 2.

Projeção dos valores dos atributos sensoriais dos vinhos avaliados, nas componentes 1 e 2, após a ACPCAT.

The first principal component distinguishes Ruby brands, located on the positive axis from White brands on the negative axis. In the Ruby brands, the attributes Ruby, Red fruits, Fruity flavour, Astringency and Floral were dominant, whereas in the White brands, attributes like Honey, Sweet taste, Alcoholic sensation, Balance, Acid taste and Moscatel are the ones that better characterize these wines. Tawny Port Wines are characterized by the ortho-nasal attribute Dried fruits.

Principle Component Analysis and Categorical Principle Component Analysis are appropriated for "good" variable selection and dimension reduction. They can be used to analyze interrelationships among a large number of variables and explain these variables in terms of their common underlying dimensions (factors) (Hair et al., 2009). The objective is to find a few linear combinations of the variables (factors) that can be used to summarize the data without losing too much information in the process. As mentioned before, the PCA is a technique that should only, in principle, be applied when the variables are quantitative, have multivariate normal distribution, linearly related to each other and the sample size should be large enough, at least five times as many observations as the number of variables to be analyzed (Hair et al., 2009). This statistical procedure requires three stages: validation of the model, factor extraction and factor rotation (optional). The first stage involves the calculation of the matrix correlation to determine the degree of association between the variables. A rule of thumb will be to consider correlations between 0.3 and 0.7. Another method of determining the appropriateness of PCA is the Bartlett test of sphericity, which provides the statistical significance that the correlation matrix has 


\begin{tabular}{cccc}
\hline \multirow{2}{*}{ Dimension } & \multirow{2}{*}{$\begin{array}{c}\text { Cronbach's } \\
\end{array}$} & Alpha $^{\text {a }}$ & \multicolumn{2}{c}{ Variance Accounted For } \\
\cline { 3 - 4 } & Total (Eigenvalue) & \% of Variance \\
\hline 1 & 0.954 & 11.383 & 49.492 \\
2 & 0.862 & 5.695 & 24.761 \\
Total & $0.984^{\mathrm{a}}$ & 17.078 & 74.253 \\
\hline
\end{tabular}

a. Total Cronbach's Alpha is based on the total Eigenvalue. significant correlations among at least some variables. A statistically significant Bartlett's test of sphericity (sig < 0.05) indicates that sufficient correlation exist among the variables (Hair et al., 2009). A third measure to quantify the degree of inter-correlations among the variables and the appropriateness of this method is the measure of sampling adequacy (MSA). Measure of sampling adequacy values must exceed 0.5 (Hair et al., 2009).

Categorical principal components analysis is a nonparametric method that quantifies categorical variables through a process called optimal quantification (also referred to as optimal scaling, or optimal scoring) (Meulman et al., 2004). Optimal quantification replaces the category labels with category quantifications in such a way that as much as possible of the variance in the quantified variables is accounted for. The most important advantages of nonlinear over linear PCA are that it incorporates nominal and ordinal variables and that it can handle and discover nonlinear relationships between variables. Because CATPCA directly analyses the data matrix and not the derived correlation matrix, there need not be the usual concern to have at least five times as many observations as the variables. In fact, CATPCA is suited for analysis in which there are more variables than objects (Meulman et al., 2004).

Table V

PCA Component Loadings

Loadings das Componentes ACP

\begin{tabular}{lrr}
\hline & \multicolumn{2}{c}{ Dimensions } \\
\cline { 2 - 3 } & \multicolumn{1}{c}{1} & $\mathbf{2}$ \\
\hline Golden & -0.732 & 0.622 \\
Ruby & 0.774 & -0.587 \\
Clean & -0.228 & -0.617 \\
Honey & -0.852 & -0.282 \\
Woody & -0.737 & 0.385 \\
Citrus & -0.352 & -0.726 \\
Sweet taste & -0.618 & -0.578 \\
Persistence & 0.849 & -0.140 \\
Alcoholic sensation & -0.808 & -0.341 \\
Acid taste & -0.405 & 0.123 \\
Soft sensation & -0.354 & -0.288 \\
Body & 0.452 & -0.100 \\
Balance & -0.770 & -0.294 \\
Spicy sensation & 0.200 & -0.188 \\
Red Fruits & 0.925 & -0.201 \\
Dried fruits & 0.148 & 0.847 \\
Fruity flavour & 0.787 & -0.049 \\
Red fruit flavor & 0.678 & -0.045 \\
Fruity & 0.864 & -0.102 \\
Astringency & 0.516 & -0.452 \\
Floral & 0.762 & -0.545 \\
Moscatel & -0.827 & -0.362
\end{tabular}

\begin{tabular}{l} 
Dried fruits flavour \\
\hline Variable Principal Normalization. \\
Table VI \\
CATPCA Model Summary \\
Sumário do Modelo ACPCAT
\end{tabular}

As mentioned before, the PCA is a technique that should only, in principle, be applied to quantitative variables. However, in sensory sciences as well as in most studies of social sciences, many of the variables used are qualitative, nominal or ordinal. Thus, we recommend using the CATPCA instead of PCA.

Table VII

CATPCA Component Loadings

Loading dos Componentes da ACPCAT

\begin{tabular}{lcc}
\hline & \multicolumn{2}{c}{ Dimension } \\
\cline { 2 - 3 } & $\mathbf{1}$ & $\mathbf{2}$ \\
\hline Golden & -0.747 & 0.658 \\
Ruby & 0.743 & -0.658 \\
Clean & -0.253 & -0.631 \\
Honey & -0.902 & -0.210 \\
Woody & -0.775 & 0.517 \\
Citrus & -0.246 & -0.949 \\
Sweet taste & -0.791 & -0.380 \\
Persistence & 0.908 & -0.067 \\
Alcoholic sensation & -0.888 & -0.342 \\
Acid taste & -0.618 & -0.008 \\
Soft sensation & -0.497 & -0.436 \\
Body & 0.460 & -0.372 \\
Balance & -0.795 & -0.244 \\
Spicy sensation & -0.037 & -0.435 \\
Red Fruits & 0.878 & -0.465 \\
Dried fruits & 0.151 & 0.865 \\
Fruity flavour & 0.767 & -0.316 \\
Red fruit flavour & 0.760 & 0.357 \\
Fruity & 0.956 & 0.238 \\
Astringency & 0.497 & -0.432 \\
Floral & 0.743 & -0.658 \\
Moscatel & -0.943 & -0.292 \\
Dried fruits flavour & 0.676 & 0.651 \\
\hline Variable Principal Normalization. &
\end{tabular}

In some related works, PCA analysis proves to demonstrate interesting results. For instances, in a work that aimed to investigate the sensory and chemical characteristics of Blanc Du Bois wines to characterize quality differences among them, PCA analysis showed specific attributes to be correlated with high- or low-quality wines (Dreyer et al., 2013). In another interesting work that aimed to improve local wine aroma and quality of wines of Cabernet Sauvignon grape-must inoculated with twelve autochthonous strains of Saccharomyces cerevisiae, PCA analysis of active aroma compounds, which contents were higher than thresholds, distinguished wines prepared into four groups according to the yeasts applied for microvinifications (Liang et al., 2013). However, as we have demonstrated in our work, the CATPCA data analysis seems to be more robust: in the CATPCA biplot the two components explained $74.253 \%$ of the total amount of initial 
variance while in the PCA biplot the two components only explained $60.325 \%$ of the total amount of initial variance. Moreover, the CATPCA model did not highlight differences among wines from winery brands while, in the PCA, Port Wines are grouped according to wine style and there are some discrimination between winery brands.

\section{CONCLUSIONS}

The work presented here allowed us to obtain two solutions that must be properly weighted and demonstrated that the application of computational resources should be taken with some care in order not to commit methodological errors.

In both analyzes were considered two components, however, the percentage of total amount of initial variance explained by CATPCA is higher (74.253\%) than the one explained by PCA analysis (60.325\%).

Clearly, the PCA violated some basic principles: the variables used were qualitative, the measure of sampling adequacy of Kaiser-Meyer-Olkin, which must exceed 0.5 gave a value of only 0.209 , indicating a not good sampling adequacy. The sample size should be large enough, at least five times as many observations as the number of variables to be analyzed, which is not the case in our study, where we had 23 variables and 28 observations. In fact, CATPCA is suited for analysis in which there are more variables than observations. Moreover, the CATPCA grouped the wines according to wine style, independently of the wines brands and there is greater cohesion between groups which seems to be appropriated to the wine samples in question.

\section{ACKNOWLEDGMENTS}

This work was partially sponsored by the Institute for Biotechnology and Bioengineering, Centre of Genomic and Biotechnology (IBB/CGB-UTAD) and by national funds through the Fundação para a Ciência e a Tecnologia, Portugal FCT, under the project PEst-OE/MAT/UI4080/2011. The authors would like to thank the entire tasting panel (GranCruz Company) that participated in this work.

\section{REFERENCES}

Dreyer E., Sims C., Rouseff R., Gray D., Sipowicz M., 2013. Sensory and compositional characteristics of Blanc Du Bois wine. Am. J. Enol. Vitic., 64, 118-125.

Esti M., Airola R.L., Moneta E., Paperaio M., Sinesio F., 2010. Qualitative data analysis for an exploratory sensory study of grechetto wine. Anal. Chem. Acta, 660, 63-67.

Gifi A., 1990. Nonlinear Multivariate Analysis. 579 p. J. Wiley, New York.

Hair J., Anderson R.E., Tatham R.L., Black W., 2009. Multivariate Data Analysis. 687 p. Prentice Hall, New Jersey.

ISO, 1977. ISO 3591 - Sensory analysis. Apparatus wine tasting glass. International Organization for Standardization, Geneva.

Liang H.-Y., Chen J.-Y., Reeves M., Han B.-Z., 2013. Aromatic and sensorial profiles of young Cabernet Sauvignon wines fermented by different Chinese autochthonous Saccharomyces cerevisiae strains. Food Res. Int., 51, 855-865.

Linting M., Meulman J.J., Groenen P.J.F., Van der Kooij A.J., 2007. Nonlinear principal components analysis: Introduction and application. Psychol. Methods, 12, 336-358.

Meilgaard M., Civille G.V., Carr B.T., 1999. Sensory evaluation techniques. 416 p. CRC Press, Boca Raton.

Meulman J.J., Van Der Kooij A.N., Heiser W., 2004. Principal Component Analysis with Nonlinear Optimal Scaling Transformations for Ordinal and Nominal Data. In: Handbook of quantitative methodology for the social sciences. 49-70. Kaplan Sage, London.

Miralles C., Moretto L., Schmitt V.G.H., 2008. Gestão de marcas e arranjos produtivos: A marca "Vinho do Porto". Comportamento Organizacional e Gestão, 14, 85-95.

Monteiro B., Vilela A., Correia E., 2014. Sensory profile of pink port wines: Development of a flavour lexicon. Flavour Frag. J., 29, 50-58.

Noble A.C., Shannon M., 1987. Profiling zinfandel wines by sensory and chemical analysis. Am. J. Enol. Vitic., 38, 1-5.

Rodriguez-Nogales J., Fernandez-Fernandez E., Vila-Crespo J., 2009. Characterization and classification of Spanish Verdejo young white wines by volatile and sensory analysis with chemometric tools. J. Sci. Food Agric., 89, 1927-1935.

Stone H., Sidel J.L., 2004. Sensory evaluation practices. 377 p. Elsevier Academic Press, San Diego.

Vilanova M., Masa A., Tardaguila J., 2009. Evaluation of the aromatic variability of Spanish grape by quantitative descriptive analysis. Euphytica, 165, 383-389.

Vilanova M., Zamuz S., Tardaguila J., Masa, A., 2008. Characterization by descriptive analysis of Vitis vinifera cv, Albariño. J. Sci. Food Agric., 88, 19-823.

Zamora M.C., Guirao M., 2002. Analyzing the contribution of orally perceived attributes to the flavor of wine. Food Qual. Prefer., 13, 275-283. 